\title{
Spectrum of opportunistic infections among HIV seropositive patients in Delhi region-a study by Delhi state AIDS control society
}

\author{
Vandana Dabla*, Anil K Gupta and Ishwar Singh \\ *Correspondence: vandana.dabla@gmail.com \\ CrossMark \\ $\leftarrow$ Click for updates
}

Delhi State AIDS Control Society, Govt of National Capital Territory of Delhi, India.

\begin{abstract}
Background: HIV infection leads to AIDS and opportunistic infections are major cause of morbidity and mortality of such patients which considerably affect the health and quality of life of people infected with HIV. Hence the present study was carried out to find out the most common opportunistic pathogen and different opportunistic pathogens infecting HIV seropositive patients in Delhi region, India.

Methods: This observational study was conducted in period from April'2013 to March'2014. During the period, total of 22,578 HIV seropositive patients were under active care of 9 ART centers of Delhi State AIDS Control Society (DSACS) till March'2014. Patients were grouped according to age as children $(\leq 15$ years of age) and adults (>15years of age) and evaluated for 13 major opportunistic infections.

Results: During the period, 2725 cases were diagnosed and treated for OIs amongst HIV seropositive patients assessed under active care of ART centers. Tuberculosis accounts for maximum cases with 28.07\%. Second most common OI reported was Candidiasis with $18.79 \%$ cases. Other OI reported were Bacterial Infections (Respiratory), Diarrhea, Bacterial Infections (skin) and Herpes Zoster with distibution of $15.5 \%, 14.53 \%, 6.64 \%$ and $3.78 \%$ respectively.

Conclusion: This study is the first study ever on cumulative reported data on OI's among HIV/AIDS patients on active care from DSACS (Delhi) showing the real-time distribution from Northern India. This will serve as a matrix for future evaluation.

Keywords: Seropositive HIV patients, opportunistic infections, spectrum, Delhi state AIDS control society, ART

Globally, there were approximately 35.3 [32.2-38.8] million people living with HIV in 2012. The adult HIV prevalence at national level is $0.27 \%$ as estimated in 2011 and has recently been estimated that 2.5 million individuals are living with HIV infection in India [1]. HIV infection leads to AIDS and major cause of morbidity and mortality of such patients are opportunistic infections and considerably affect the health and quality of life of people infected with HIV [2].

The depletion of T-lymphocytes which result from the proliferation of HIV causes the immune system to become severely compromised and the usually benign infectious agents become pathogenic. A number of microorganisms can be responsible for such opportunistic infections (Ol's) in HIV-

infected persons who have progressed to AIDS [3,4]. Global evidence suggests that the overall incidence of opportunistic diseases increases with the degree of immunosuppression resulting from HIV disease progression $[5,6]$.

More than 9.7 million people living with HIV in low and middle income countries were receiving ART at the end of 2012. Of this, about 640000 were children. The Antiretroviral Therapy (ART) started in the mid 1990s was instrumental in reducing the mortality related to HIV infection. ART not only reduces the incidence of Ols but also improves survival rate of PLHIVs. In India, Treatment of Opportunistic Infections (OI) is one of the main goal of comprehensive management to People living with HIV/AIDS (PLHIV) served through Care, Support and Treatment (CST) component of the, National AIDS Control
\end{abstract}

\section{Introduction}


Dabla et al. Journal of Medical Disorders 2015,

http://www.hoajonline.com/journals/pdf/2053-3659-3-1.pdf

doi: 10.7243/2053-3659-3-1

Programme (NACO), Department of AIDS Control, Government of India. Under this initiative, patients have been provided access to free antiretroviral therapy (ART) for a decade (India had its first functional ART center in April'2004) and around 0.75 million patients are receiving free ART therapy (second highest in the world) through 425 ART centers, 840 Link ART centers, 37 ART plus centres and 10 Center of Excellence (CoE) till March 2014. NACO reported in their Annual report of 201213 about up gradation of their regional Pediatric ART centers into Pediatric Center of Excellence (PCoE). PCoE play a key role in management of complicated opportunistic infections in Pediatrics. The beneficiaries of Care, Support \& Treatment Services till December 2012 were shown in Table 1 [7].

Table 1. NACO report on beneficiaries of care, support \& treatment services till December 2012.

\begin{tabular}{ll}
\hline Services/Beneficiaries & Achievement as on Dec 2012 \\
\hline Adults alive and on ART & $5,70,620$ \\
Children alive and on ART & 34,367 \\
Opportunistic Infections & $4,84,925$ \\
treated during 2012-13 & \\
(till December 2012) & \\
Persons alive and on second & 5,503 \\
line ART & \\
\hline
\end{tabular}

In Delhi, the number of PLHIV Alive and on First line ART by the end of March 2014 were 16038 among which 1021 were children below 15 years of age. As per World Health Organisation (WHO), online data record of Oct 2013, the most common life-threatening opportunistic infection affecting people living with HIV/AIDS is Tuberculosis (TB). It kills nearly a quarter of a million people living with HIV each year. It is the number one cause of death among HIV-infected people in Africa, and a leading cause of death in this population worldwide. Tuberculosis is the most commonly reported $\mathrm{OI}$ among HIV-infected individuals in India [8,9]. Oral candidiasis, herpes zoster, cryptococcal meningitis, cerebral toxoplasmosis, and cytomegalovirus retinitis includes other commonly reported Ois $[10,11]$.

Hence the present study was carried out to find out the most common opportunistic pathogen and different opportunistic pathogens infecting HIV seropositive patients in Delhi region, India.

\section{Materials and methods}

This observational study was conducted in period from April 2013 to March' 2014. During the period, total of 22,578 HIV seropositive patients were under active care of 9 ART centers of Delhi State AIDS Control Society (DSACS) till March'2014. Patients were grouped according to age as Children ( $\leq 15$ years of age) and Adults (>15years of age). These patients included PLHIVs put on Antiretroviral therapy and PLHIVs not started on Antiretroviral therapy. They reportedly visited ART centers at least twice in a year or more frequently from April' 2013 to March'2014 and were assessed and treated for Opportunistic Infections. The clinical assessment and examination of the cases was done by Senior Medical Officer/Medical Officer of the respective ART center. Laboratory investigations were prescribed on case to case basis. With CD4 cell count test advised every six months.

These patients presented of various signs and symptoms like weight loss, loss of appetite, chronic diarrhoea, dysphagia, chronic cough etc. However some patients came for voluntary testing as well. Patients were evaluated for 13 major opportunistic infections. A specific opportunistic infection was diagnosed on the basis of standard clinical definition and by laboratory procedures $[12,13]$. Tuberculosis is diagnosed and treated as per Revised National Tuberculosis Control Programme (RNTCP) guidelines.

\section{Results}

In the capital of India, with total population of more than Two billion, the prevalence of HIV is $0.30 \%$. The total HIV seropositive people registered at ART centers of Delhi till March 2014 were reportedly 42,590, and total number of HIV seropositive people ever started on ART was 23128. The cumulative number of people living with HIV in Active Care at the end of March 2014 was 22578 (16038 PLHIVs on antiretroviral treatment (ART) and 6540 PLHIVs registered in the programme but not initiated on ART). Among this group, 59.25\% were males, $32.39 \%$ were females, $1.40 \%$ was transgender/transsexual and $6.94 \%$ were children $\leq 15$ years of age. During the period, 2725 cases were diagnosed and treated for Ols amongst HIV seropositive patients assessed under active care of ART centers. The distribution pattern of different opportunistic infections cases among PLHIVs were recorded and shown in Table 2. Tuberculosis accounts for maximum cases with $28.07 \%$. Second most common Ol reported was Candidiasis with $18.79 \%$ cases. Other Ol reported were Bacterial Infections (Respiratory), Diarrhea, Bacterial Infections (skin) and Herpes Zoster with distribution of $15.5 \%, 14.53 \%, 6.64 \%$ and $3.78 \%$ respectively. The distribution of different Ol's in percentage and total number is shown in Figure 1.

Other infections like Pneumocystic Carinii Pneumonia (PCP), CMV retinitis, Cryptococcal Meningitis, Mycobacterium Avium Complex (MAC) were of low incidence; respectively $1.14 \%$, $0.55 \%, 0.88 \%$ and $0.48 \%$. Out of all, $6.57 \%$ were categorized as "others", which included cases showing sign \& symptoms of psychological disorder, lymphadenopathy or other infections not listed in the categories as mentioned in Table 2.

Out of 2725 cases assessed, 2276 (83.52\%) were adults (>15 years of age) and 449 (16.54\%) were children ( $\leq 15$ years of age). Table 2 shows the distribution of Ol's among Adults and Children under each category of Ol's. Bacterial Infections (Respiratory) is observed to be the commonest Ol among children with prevalence of $36.3 \%$ against $10.09 \%$ prevalence in adults. Likewise, Diarrhea accounts for second commonest Ol in 
Dabla et al. Journal of Medical Disorders 2015,

http://www.hoajonline.com/journals/pdf/2053-3659-3-1.pdf

Table 2. Distribution of opportunistic infections among adults and children in each category.

\begin{tabular}{lllllll}
\hline $\begin{array}{l}\text { Type of OI } \\
\text { (n=2725) }\end{array}$ & $\begin{array}{l}\text { Adult } \\
\text { (No.of cases) }\end{array}$ & Adult (\%) & $\begin{array}{l}\text { Pediatric } \\
\text { (No.of cases) }\end{array}$ & $\begin{array}{l}\text { Pediatric (\%) } \\
\text { Tuberculosis }\end{array}$ & $\begin{array}{l}\text { Total prevalence } \\
\text { (Adult+Pediatric) }\end{array}$ & $\begin{array}{l}\text { Total prevalence } \\
\text { (Adult+Pediatric) }\end{array}$ \\
\hline Candidiasis & 746 & 32.8 & 19 & 4.2 & 765 & 28.1 \\
Diarrhea & 485 & 21.3 & 27 & 6.0 & 512 & 18.8 \\
Pneumocystic carinii pneumonia & 26 & 15.0 & 54 & 12.0 & 396 & 14.5 \\
(PCP) & 342 & 1.1 & 5 & 1.1 & 31 & 1.1 \\
Herpes zoster & 95 & 4.2 & 8 & 1.8 & 103 & 3.8 \\
Bacterial infections (respiratory) & 247 & 10.9 & 163 & 36.3 & 410 & 15.0 \\
Cryptococcal meningitis & 24 & 1.1 & 0 & 0.0 & 24 & 0.9 \\
Toxoplasmosis & 4 & 0.2 & 0 & 0.0 & 4 & 0.1 \\
CMV retinitis & 15 & 0.7 & 0 & 0.0 & 15 & 0.6 \\
MAC & 8 & 0.4 & 5 & 1.1 & 13 & 0.5 \\
Bacterial infections(skin) & 136 & 6.0 & 45 & 10.0 & 181 & 6.6 \\
Herpes simplex & 19 & 0.8 & 5 & 1.1 & 24 & 0.9 \\
Malignancy & 22 & 1.0 & 46 & 10.2 & 68 & 2.5 \\
Others & 107 & 4.7 & 72 & 16.0 & 179 & 6.6 \\
Total & 2276 & 83.5 & 449 & 16.5 & 2725 & 100 \\
\hline
\end{tabular}

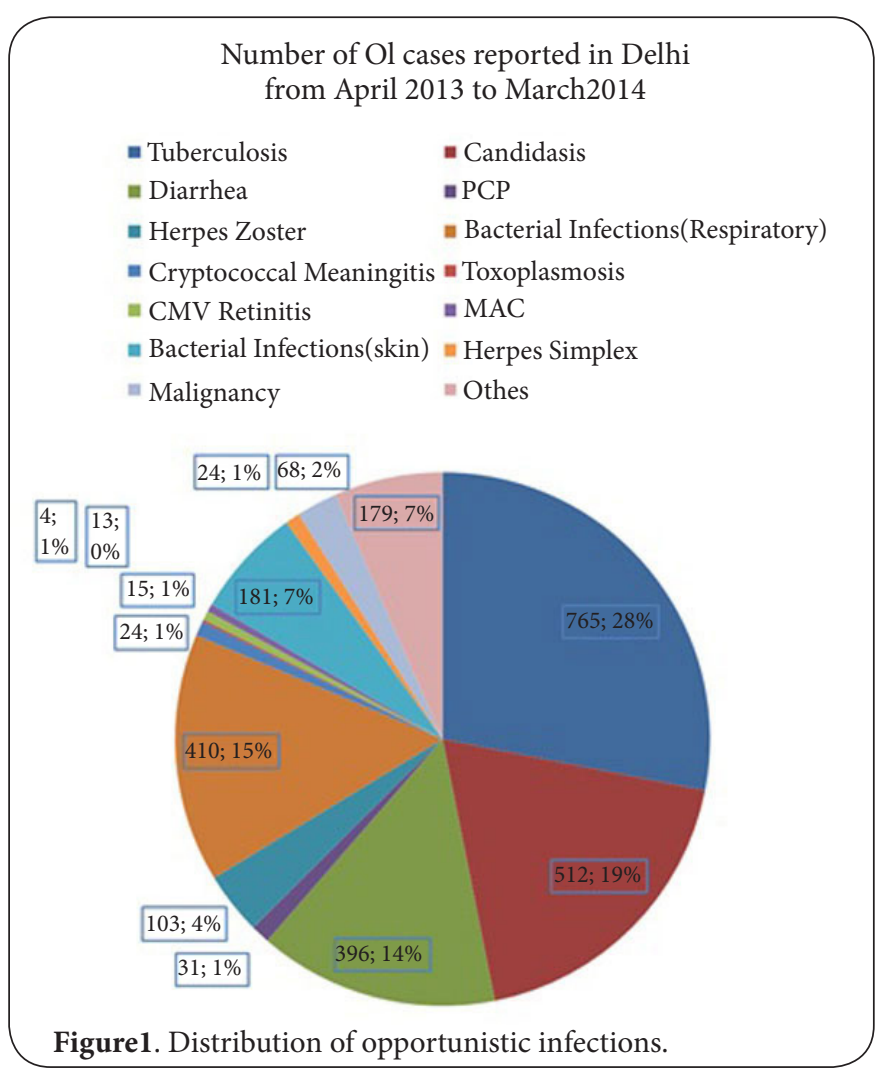

children, followed by Malignancy and Bacterial skin infections. Tuberculosis is demonstrated as the commonest Ol, with total of 765 cases $(28.07 \%)$. Further, $373(13.69 \%)$ of cases were of pulmonary tuberculosis and 392 (14.38\%) were of extra pulmonary tuberculosis of entire cohort. Distribution of pulmonary and extra pulmonary tuberculosis among adults and children cases is shown in Figure 2.

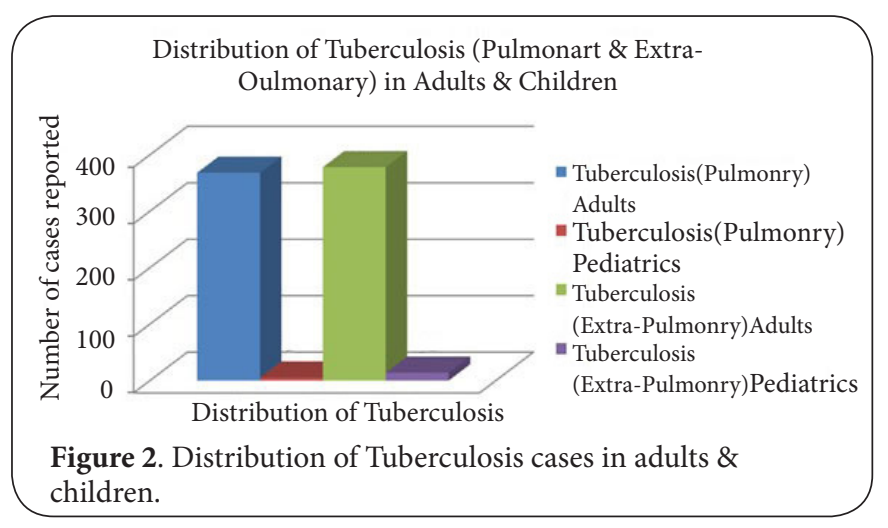

\section{Discussion}

Although the Human Immunodeficiency Viruses are the initial causative agents in AIDS, most of the morbidity and mortality seen in the case of AIDS patient results from the opportunistic infections which take advantage of the lowered cellular and humoral defence mechanisms of the patient. The infections encountered in the AIDS patients are of wide variety including bacteria, fungi, viruses and protozoa. Tuberculosis (TB) is the most common life-threatening opportunistic infection affecting people living with HIV/AIDS as per World Health Organisation (WHO) online data record of Oct 2013. It is observed to be the commonest cause of death among HIV-infected people in Africa, and a leading cause of death 
Dabla et al. Journal of Medical Disorders 2015,

http://www.hoajonline.com/journals/pdf/2053-3659-3-1.pdf

doi: 10.7243/2053-3659-3-1

in this population worldwide. It kills nearly a quarter of a million people living with HIV every year [14]. Mycobacterium tuberculosis was the commonest isolate reported responsible for Tuberculosis in few studies from India $[15,16]$. Similar finding is reported in our study, with TB as the most prevalent Ol with $28.07 \%$ prevalence $(32.8 \%$ in adults and $4.2 \%$ in pediatric group). Higher incidence of TB (71.1\%) was also reported in New Delhi by Sharma et al. [17]. In the current study, out of 765 total reported cases of TB, 51.2\% (392 cases) were Extra pulmonary in nature while $48.8 \%$ (373 cases) were had Pulmonary TB infection. Kumarasamy et al., from southern India in a retrospective analysis of $594 \mathrm{HIV}$-positive patients however reported higher incidence of Pulmonary Tuberculosis (PTB) (49.3\%) in respect to Extrapulmonary Tuberculosis (EPTB) (11\%) [18]. This diverse finding may further be researched for susceptibility of PLHIVs towards acquiring pulmonary and extra pulmonary TB.

Gastrointestinal Infections are very recurrent in patients living with HIV/AIDS. It had been reported that in AIDS patients the occurrence of Diarrhea in developed countries is 30-60 per cent whereas it is $90 \%$ in developing countries. C. parvum (54\%) was the predominant pathogen among the opportunistic parasites. Several studies from India and other parts of the world also have reported the same [19-21]. In our study, Diarrhoea presented as third commonest Ol with $14.53 \%$ cases. Even though Pneumocystic carinii pneumonia (PCP) is one of the most common opportunistic infections in AIDS patients, the rate of its recurrence among HIV/AIDS patients in tropical and developing countries is generally lower compared to that in industrialised nations [22]. Here also, the prevalence of PCP is demonstrated lower with 1.1\% in adults and children.

A study from south India reported Oral Candidasis is in 59\% of AIDS cases [23]. Since candidiasis is a frequent infection among PLHAs, it has been documented that it occurs in up to $70 \%$ of HIV infected cases [24]. Similar conclusions are obtained from current study that the second most common Ol among PLHAs is candidiasis with $18.79 \%$ of prevalence. Saha et al., from Kolkata reported oral candidiasis (53.43\%), chronic diarrhoea (47.05\%), and TB (35.29\%) as commonest opportunistic infection [25]. In another study, Patel from Ahmedabad revealed that candidiasis was the commonest isolate (32.67\%), followed by TB (22.71\%) [26]. Although TB is the most common Ol in adult but Respiratory bacterial infection is the commonest Ol reported among children in our study.

\section{Conclusion}

The first case of AIDS in India was reported in 1986. Now India is the country with the second largest population of HIV infected individuals. The emergence and pandemic spread of AIDS constitute the greatest challenge to public health in modern time. With the changing scenario of AIDS epidemic, a host of opportunistic infections add to the present endemic state of some already existing infections like tuberculosis.
The present study reflects that Tuberculosis presents as the commonest $\mathrm{Ol}$ in adults and overall population whereas Respiratory bacterial infections are the commonest Ol among children among the HIV/AIDS patients of Delhi. This study proves that the spectrum of opportunistic infections among various patient groups varies significantly. Moreover, this is the first study to assess cumulative data on Ols among HIV/ AIDS patients on active care from (Delhi Region) showing the real-time distribution from Northern India and thus would serve as a matrix for future evaluation.

\section{Competing interests}

The authors declare that they have no competing interests.

\section{Authors' contributions}

\begin{tabular}{|l|c|c|c|}
\hline Authors' contributions & VD & AKG & IS \\
\hline Research concept and design & $\checkmark$ & $\checkmark$ & -- \\
\hline Collection and/or assembly of data & $\checkmark$ & -- & $\checkmark$ \\
\hline Data analysis and interpretation & $\checkmark$ & -- & $\checkmark$ \\
\hline Writing the article & $\checkmark$ & -- & -- \\
\hline Critical revision of the article & $\checkmark$ & $\checkmark$ & -- \\
\hline Final approval of article & $\checkmark$ & $\checkmark$ & $\checkmark$ \\
\hline Statistical analysis & $\checkmark$ & -- & -- \\
\hline
\end{tabular}

\section{Acknowledgement}

Authors wish to acknowledge \& pay sincere thanks to all the DSACS Doctors, Technical Staff \& other staff for their continuous participation to patient services.

Publication history

Senior Editor: Eric Murillo Rodriguez, Anahuac Mayab University, Mexico.

Received: 14-Feb-2015 Final Revised: 12-May-2015

Accepted: 19-May-2015 Published: 29-May-2015

\section{References}

1. AIDS by the numbers. UNAIDS. 2013; 1-11. | Website

2. Kaplan JE, Benson C, Holmes KK, Brooks JT, Pau A and Masur H. Guidelines for prevention and treatment of opportunistic infections in HIV-infected adults and adolescents: recommendations from CDC, the National Institutes of Health, and the HIV Medicine Association of the Infectious Diseases Society of America. MMWR Recomm Rep. 2009; 58:1-207. | Article | PubMed

3. Cheesbrough M. Paediatric HIV disease. District Laboratory Practice in Tropical Countries. Cambridge University Press. 2000; 256. I Pdf

4. Constantine NT, Saville RD and Dax EM. Retroviral testing and Quality Assurance. Essentials for Laboratory Diagnosis. 2005; 56-58. | Book

5. Ghate M, Deshpande S, Tripathy S, Nene M, Gedam P, Godbole S, Thakar $M$, Risbud A, Bollinger R and Mehendale S. Incidence of common opportunistic infections in HIV-infected individuals in Pune, India: analysis by stages of immunosuppression represented by CD4 counts. Int J Infect Dis. 2009; 13:e1-8. | Article | PubMed

6. Carmo RA, Guimaraes MD, Moura AS, Neiva AM, Versiani JB, Lima LV, Freitas LP and Rocha MO. The influence of HCV coinfection on clinical, immunological and virological responses to HAART in HIV-patients. Braz J Infect Dis. 2008; 12:173-9. | Article | PubMed

7. National AIDS Control Organisation. Department of AIDS Control. Ministry of Health \& Family Welfare. Annual Report. 2012-13. | Website

8. Damtie D, Yismaw G, Woldeyohannes D and Anagaw B. Common 
Dabla et al. Journal of Medical Disorders 2015,

http://www.hoajonline.com/journals/pdf/2053-3659-3-1.pdf

doi: 10.7243/2053-3659-3-1

opportunistic infections and their CD4 cell correlates among HIVinfected patients attending at antiretroviral therapy clinic of Gondar University Hospital, Northwest Ethiopia. BMC Res Notes. 2013; 6:534. Article | PubMed Abstract | PubMed Full Text

9. Cain KP, Anekthananon T, Burapat C, Akksilp S, Mankhatitham W, Srinak C, Nateniyom S, Sattayawuthipong W, Tasaneeyapan T and Varma JK. Causes of death in HIV-infected persons who have tuberculosis, Thailand. Emerg Infect Dis. 2009; 15:258-64. | Article | PubMed Abstract I PubMed Full Text

10. Vajpayee M, Kanswal S, Seth P and Wig N. Spectrum of opportunistic infections and profile of CD4+ counts among AIDS patients in North India. Infection. 2003; 31:336-40. | Article | PubMed

11. Sharma SK, Kadhiravan T, Banga A, Goyal T, Bhatia I and Saha PK. Spectrum of clinical disease in a series of $\mathbf{1 3 5}$ hospitalised HIV-infected patients from north India. BMC Infect Dis. 2004; 4:52. | Article | PubMed Abstract | PubMed Full Text

12. Guidelines for national human immunodeficiency virus case surveillance, including monitoring for human immunodeficiency virus infection and acquired immunodeficiency syndrome. Centers for Disease Control and Prevention. MMWR Recomm Rep. 1999; 48:1-27, 29-31. | Article | PubMed

13. Guidelines for prophylaxis against Pneumocystis carinii pneumonia for persons infected with human immunodeficiency virus. MMWR Morb Mortal Wkly Rep. 1989; 38 Suppl 5:1-9. | PubMed

14. National guidelines for clinical management of HIV/AIDS. National AIDS Control Organisation, Ministry of Health and Family Welfare. New Delhi: Government of India. 2000; 17-52. I Website

15. Merchant RH, Oswal JS, Bhagwat RV and Karkare J. Clinical profile of HIV infection. Indian Pediatr. 2001; 38:239-46. | Article | PubMed

16. Pol RR, Shepur TA and Ratageri VH. Clinico-laboratory profile of pediatric HIV in Karnataka. Indian J Pediatr. 2007; 74:1071-5 5. | Article | PubMed

17. Sharma SK, Kadhiravan T, Banga A, Goyal T, Bhatia I and Saha PK. Spectrum of clinical disease in a series of $\mathbf{1 3 5}$ hospitalised HIV-infected patients from north India. BMC Infect Dis. 2004; 4:52. | Article | PubMed Abstract | PubMed Full Text

18. Kumarasamy N, Solomon S, Flanigan TP, Hemalatha R, Thyagarajan $\mathrm{SP}$ and Mayer $\mathrm{KH}$. Natural history of human immunodeficiency virus disease in southern India. Clin Infect Dis. 2003; 36:79-85. | Article | PubMed

19. Dwivedi KK, Prasad G, Saini S, Mahajan S, Lal S and Baveja UK. Enteric opportunistic parasites among HIV infected individuals: associated risk factors and immune status. Jpn J Infect Dis. 2007; 60:76-81. | Article | PubMed

20. Sadraei J, Rizvi MA and Baveja UK. Diarrhea, CD4+ cell counts and opportunistic protozoa in Indian HIV-infected patients. Parasitol Res. 2005; 97:270-3. | Article | PubMed

21. Wiwanitkit $V$. Intestinal parasitic infections in Thai HIV-infected patients with different immunity status. BMC Gastroenterol. 2001; 1:3. | Article | PubMed Abstract | PubMed Full Text

22. Russian DA and Kovacs JA. Pneumocystis carinii in Africa: an emerging pathogen? Lancet. 1995; 346:1242-3. | Article | PubMed

23. Singh A, Bairy I and Shivananda PG. Spectrum of opportunistic infections in AIDS cases. Indian J Med Sci. 2003; 57:16-21. | Article | PubMed

24. Kumarasamy N, Vallabhaneni S, Flanigan TP, Mayer KH and Solomon S. Clinical profile of HIV in India. Indian J Med Res. 2005; 121:377-94. | Pdf I PubMed

25. Saha K, Firdaus R, Santra P, Pal J, Roy A, Bhattacharya MK, Chakrabarti $S$ and Sadhukhan PC. Recent pattern of Co-infection amongst HIV seropositive individuals in tertiary care hospital, Kolkata. Virol J. 2011; 8:116. | Article | PubMed Abstract | PubMed Full Text

26. Patel SD, Kinariwala DM and Javadekar TB. Clinico-microbiological study of opportunistic infection in HIV seropositive patients. Indian J Sex Transm Dis. 2011; 32:90-3. | Article | PubMed Abstract | PubMed Full $\underline{\text { Text }}$
Citation:

Dabla V, Gupta AK and Singh I. Spectrum of opportunistic infections among HIV seropositive patients in Delhi region-a study by Delhi state AIDS control society. J Med Disord. 2015; 3:1. http://dx.doi.org/10.7243/2053-3659-3-1 